\title{
Article \\ Evodiamine Inhibits Helicobacter pylori Growth and Helicobacter pylori-Induced Inflammation
}

\author{
Ji Yeong Yang ${ }^{1,2} \oplus$, Jong-Bae Kim ${ }^{2}\left(\right.$, Pyeongjae Lee ${ }^{3}$ and Sa-Hyun Kim ${ }^{4, *}(\mathbb{C}$ \\ 1 Division of Crop Foundation, National Institute of Crop Science (NICS), \\ Rural Development Administration (RDA), Wanju 55365, Korea; yjy90@korea.kr \\ 2 Department of Biomedical Laboratory Science, College of Health Sciences, Yonsei University, \\ Wonju 26493, Korea; kimjb70@yonsei.ac.kr \\ 3 School of Oriental Medicine and Bio Convergence Sciences, Semyung University, Jaecheon 27136, Korea; \\ pjlee1@semyung.ac.kr \\ 4 Department of Clinical Laboratory Science, Semyung University, Jecheon 27136, Korea \\ * Correspondence: science4us@semyung.ac.kr
}

Citation: Yang, J.Y.; Kim, J.-B.; Lee, P.; Kim, S.-H. Evodiamine Inhibits Helicobacter pylori Growth and Helicobacter pylori-Induced Inflammation. Int. J. Mol. Sci. 2021, 22, 3385. https://doi.org/10.3390/ ijms22073385

Academic Editors: Alessandra Tosco and Amalia Porta

Received: 26 February 2021

Accepted: 23 March 2021

Published: 25 March 2021

Publisher's Note: MDPI stays neutral with regard to jurisdictional claims in published maps and institutional affiliations.

Copyright: (c) 2021 by the authors. Licensee MDPI, Basel, Switzerland. This article is an open access article distributed under the terms and conditions of the Creative Commons Attribution (CC BY) license (https:// creativecommons.org/licenses/by/ $4.0 /)$.

\begin{abstract}
Helicobacter pylori (H. pylori) classified as a class I carcinogen by the World Health Organization (WHO) plays an important role in the progression of chronic gastritis and the development of gastric cancer. A major bioactive component of Evodia rutaecarpa, evodiamine, has been known for its anti-bacterial effect and anti-cancer effects. However, the inhibitory effect of evodiamine against $H$. pylori is not yet known and the inhibitory mechanisms of evodiamine against gastric cancer cells are yet to be elucidated concretely. In this study, therefore, anti-bacterial effect of evodiamine on $H$. pylori growth and its inhibitory mechanisms as well as anti-inflammatory effects and its mechanisms of evodiamine on H. pylori-induced inflammation were investigated in vitr. Results of this study showed the growth of the H. pylori reference strains and clinical isolates were inhibited by evodiamine. It was considered one of the inhibitory mechanisms that evodiamine downregulated both gene expressions of replication and transcription machineries of H. pylori. Treatment of evodiamine also induced downregulation of urease and diminished translocation of cytotoxin-associated antigen A (CagA) and vacuolating cytotoxin A (VacA) proteins into gastric adenocarcinoma (AGS) cells. This may be resulted from the reduction of CagA and VacA expressions as well as the type IV secretion system (T4SS) components and secretion system subunit protein A (SecA) protein which are involved in translocation of CagA and VacA into host cells, respectively. In particular, evodiamine inhibited the activation of signaling proteins such as the nuclear factor $\mathrm{k}$-light-chain-enhancer of activated B cells (NF-kB) and the mitogen-activated protein kinase (MAPK) pathway induced by H. pylori infection. It consequently might contribute to reduction of interleukin (IL)-8 production in AGS cells. Collectively, these results suggest anti-bacterial and anti-inflammatory effects of evodiamine against $H$. pylori.
\end{abstract}

Keywords: Evodia rutaecarpa; evodiamine; Helicobacter pylori; IL-8; inflammation; natural compound; $\mathrm{NF}-\kappa \mathrm{B}$

\section{Introduction}

Helicobacter pylori (H. pylori) infection has been known to be a common cause among certain factors responsible for high rates of gastric cancer including age, family history, smoking, etc. [1,2]. Therefore, a concerted effort for eradication of H. pylori infection still seems to be necessary for health promotion worldwide.

DNA replication and transcription are vital steps for survival and propagation of all known living organisms including $H$. pylori. DnaA, a chromosomal replication initiator protein, forms the complex with DnaB, DNA-unwinding helicase. DnaG primase synthesizes primers [3,4]. DNA polymerase III consists of core polymerases (DnaE, DnaQ and HolE), sliding clamp (DnaN) and clamp-loader (DnaX, HolA, HolB, HolC and HolD) [5]. 
Bacterial RNA polymerase consists of five subunits [6]. The gene rpoA and rpoB encode the $\alpha$ and $\beta$ subunit, respectively. Both $r p o \mathrm{~N}$ and $r p o \mathrm{D}$ gene encode the $\sigma$ factors.

One of the essential factors for successful colonization of $H$. pylori in the strongly acidic gastric lumen is the enzyme urease, which is a heterodimer composed of structural subunits UreA and UreB [7-10]. Once H. pylori survives in acidic $\mathrm{pH}$ of lumen during the early stages of gastric infection, the bacterium reaches the safe mucus layer and starts colonizing the gastric mucosa [11].

H. pylori, which has successfully colonized in gastric epithelial cells, induces an immune response through mechanisms such as the secretion of various inflammatory cytokines [12]. Especially, IL-8 is one of the major inflammatory chemokines. H. pylorimediated IL-8 secretion in gastric epithelial cells requires activation of the nuclear factor $\kappa$-light-chain-enhancer of activated B cells (NF- $\mathrm{KB})[13,14]$. Representative virulence factors contributing to these immune responses as well as pathogenesis associated with $\mathrm{H}$. pyloriinfections are cytotoxin-associated gene A (CagA) and vacuolating cytotoxin A (VacA).

CagA is injected into host cells by the type IV secretion system (T4SS) comprising 12 subunits including 11 essential proteins (VirB1 VirB11) and VirD4 [15-17]. The injected CagA into host cell leads full activation of the mitogen-activated protein kinase (MAPK) pathway [18,19], which may act as the upstream signaling for the activation of NF- $\mathrm{KB}$ [20]. Secretion system subunit protein A (SecA) is an ATPase that provides energy for translocation into the cell membrane of VacA [21-24]. The VacA protein triggers intracellular signal transductions related to inflammation, vaculoation and apoptosis.

Evodia rutaecarpa is commonly used as herbal remedy in traditional Chinese medicine for the treatment of abdominal pain, dysentery or amenorrhea. We have previously described the minimum inhibitory concentrations (MICs) of the different methanol concentration extracts against $H$. pylori and the effect on virulence factors of $H$. pylori [25]. Major bioactive ingredients of Evodia rutaecarpa include evocarpine, evodiamine, etc. [26].

Evodiamine has been reported to exhibit numerous pharmacological effects including vasodilatory [27], anti-obesity [28], anti-allergic [29], anti-inflammatory [30] and anticancer effects [31-33] and chemical structure of evodiamine is shown in Figure 1A. In this study, effects of evodiamine on the expressions of the MAPK and NF- $\mathrm{BB}$-mediated signaling pathway induced by virulence factors of $H$. pylori, as well as its inhibitory effect of evodiamine on $H$. pylori growth and its inhibitory mechanisms were investigated in vitro. 
(A)

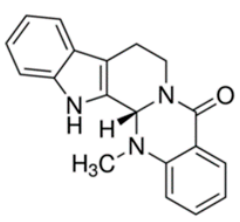

(B)

(D)

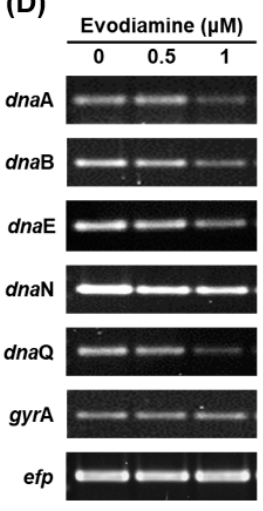

(E)
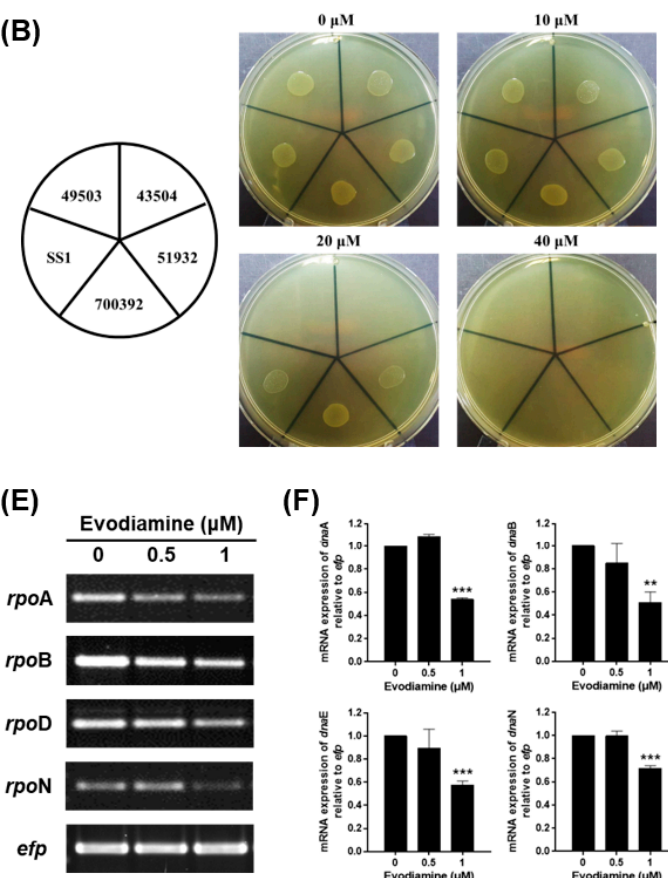

(F)
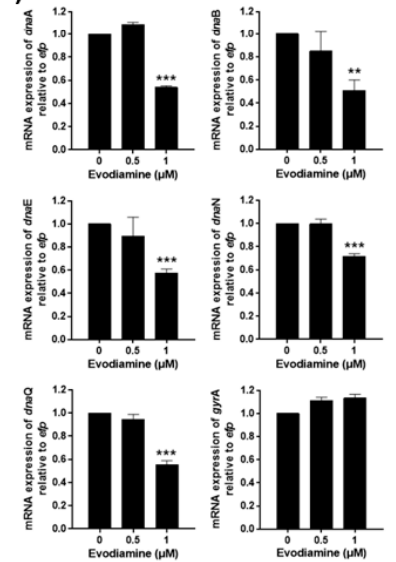
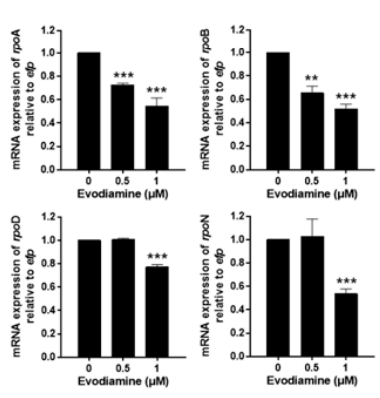

(C)
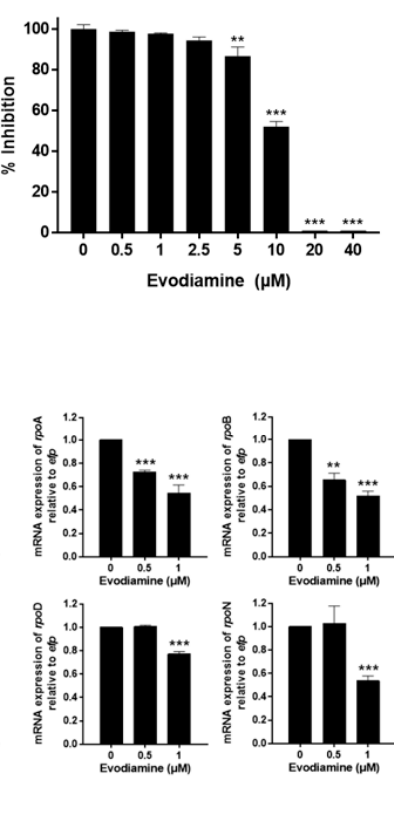

Figure 1. Anti-bacterial activity of evodiamine against $H$. pylori and downregulation of replication and transcription genes of H. pylori. (A) Chemical structure of evodiamine. (B) The MIC of evodiamine against five $H$. pylori reference strains (ATCC 49503, ATCC 43504, ATCC 51932, ATCC 700392 and SS1) was determined by agar dilution method. (C) The MIC of evodiamine against H. pylori ATCC 49503 strain was confirmed by broth dilution method. Optical density of bacterial broth was measured at $600 \mathrm{~nm}$ wavelength by spectrophotometry. H. pylori was treated with indicated concentrations of evodiamine $(0.5$ and $1 \mu \mathrm{M})$ for $72 \mathrm{~h}$. RNA was subjected to RT-PCR to detect the mRNA expression levels of (D) replication machineries $(d n a \mathrm{~A}, d n a \mathrm{~B}, d n a \mathrm{E}, d n a \mathrm{~N}, d n a \mathrm{Q}$ and $g y r \mathrm{~A})$ and $(\mathrm{E})$ transcription machineries $(r p o \mathrm{~A}, r p o \mathrm{~B}, r p o \mathrm{D}$ and $r p o \mathrm{~N})$. The expression of efp was used as an internal control. (F) Each band intensity was normalized to efp. Data are presented as mean \pm SEM of three independent experiments and analyzed by Student's $t$-test $\left({ }^{* *} p<0.01\right.$ and $\left.{ }^{* * *} p<0.001\right)$.

\section{Results}

2.1. Inhibitory Effect of Evodiamine on the Growth of H. pylori by Downregulation of Replication and Transcription Genes

An agar dilution test was performed to determine the minimum inhibitory concentration (MIC) of evodiamine against clinical isolates collected from gastric biopsies as well as five H. pylori reference strains (ATCC 49503, ATCC 43504, ATCC 51932, ATCC 700392 and SS1). As a result, the MIC of evodiamine against ATCC 49503 and 43504 strains was $20 \mu \mathrm{M}$ and that of ATCC 51932, 700392 and SS1 was $40 \mu \mathrm{M}$ (Figure 1B). Among the 50 clinical isolates, the MIC of $42 \%(21 / 50)$ was $20 \mu \mathrm{M}, 20 \%(10 / 50)$ was $10 \mu \mathrm{M}, 14 \%(7 / 50)$ was less than $5 \mu \mathrm{M}, 14 \%(7 / 50)$ was $40 \mu \mathrm{M}$ and $10 \%(5 / 50)$ was more than $80 \mu \mathrm{M}$ (Table 1$)$. Because the bacteria were grown in the broth for subsequent experiments, the broth dilution test was conducted to determine the MIC of evodiamine against H. pylori ATCC 49503, representatively. Bacterial growth suppression was observed at $5 \mu \mathrm{M}$ and significant inhibition was observed above $10 \mu \mathrm{M}$ (Figure 1C). Based on these results, it was demonstrated that evodiamine has an anti-bacterial effect on H. pylori. In particular, these results showed the anti-bacterial effect of evodiamine was similar on H. pylori clinical isolates as well as the reference strains. 
Table 1. MIC of evodiamine on H. pylori clinical isolates.

\begin{tabular}{ccc}
\hline $\begin{array}{c}\text { Evodiamine } \\
\text { Concentration }(\mu \mathrm{M})\end{array}$ & \multicolumn{2}{c}{ Number of Strains (\%) } \\
\hline$\leq 5$ & 7 & $(14 \%)$ \\
10 & 10 & $(20 \%)$ \\
20 & 21 & $(42 \%)$ \\
40 & 7 & $(14 \%)$ \\
$\geq 80$ & 5 & $(10 \%)$ \\
\hline Total & 50 & $(100 \%)$ \\
\hline
\end{tabular}

To elucidate how evodiamine inhibits the growth of H. pylori, expressions of replication and transcription machinery of $H$. pylori were evaluated. The results show that the mRNA expressions of $d n a \mathrm{~A}, d n a \mathrm{~B}, d n a \mathrm{E}, d n a \mathrm{~N}$ and $d n a \mathrm{Q}$ among the replication machinery of $H$. pylori were decreased in $H$. pylori treated with sub-MIC levels of evodiamine, although the expression of the gyrA gene remained constant compared to the evodiamine-non-treated H. pylori (Figure 1D,F). Furthermore, evodiamine suppressed the rpo A, rpoB, rpoD and $r p o \mathrm{~N}$ expressions associated with transcription machinery of $H$. pylori compared to the evodiamine-non-treated $H$. pylori (Figure $1 \mathrm{E}, \mathrm{F}$ ). Therefore, the reason why the evodiamine inhibits the growth of $H$. pylori is in part that the replication and transcription factors necessary for the growth of bacteria were suppressed by evodiamine treatment.

\subsection{Downregulation of Urease in H. pylori Treated with Evodiamine}

The expression of urease is essential for $H$. pylori to colonize the gastric mucosa to survive in the highly acidic environment. Therefore, it was examined whether evodiamine affects the urease of $H$. pylori which in turn affects bacterial attachment of gastric mucosa. The mRNA and protein expressions of the $\alpha$ and $\beta$ subunit consisting the urease of $H$. pylori were confirmed by RT-PCR and Western blot, respectively. As a result, it was confirmed that the mRNA expressions of both ure $\mathrm{A}$ and ureB significantly decreased with the treatment of evodiamine (Figure 2A,B). The expression of UreA protein was decreased by evodiamine in a dose-dependent manner and that of UreB seemed to be slightly decreased (Figure 2C).

To confirm the effect of the reduction of UreA and UreB expressions on urease activity, the amount of ammonia produced by urease activity was measured. The amount of ammonia in the media supernatant was $38.1 \mu \mathrm{g} / \mathrm{dL}$ at $0 \mu \mathrm{M}, 33.4 \mu \mathrm{g} / \mathrm{dL}$ at $0.5 \mu \mathrm{M}$ and 32.8 $\mu \mathrm{g} / \mathrm{dL}$ at $1 \mu \mathrm{M}$. The amount of ammonia in cell lysate was $88.5,82.0$ and $78.0 \mu \mathrm{g} / \mathrm{dL}$ at 0 , 0.5 and $1 \mu \mathrm{M}$, respectively. Total amount of ammonia decreased by $7 \%$ at $0.5 \mu \mathrm{M}$ and $11 \%$ at $1 \mu \mathrm{M}$ treated group when compared to the untreated group (Figure 2D). The production of ammonia in the supernatant and cell lysate seems to be a result of the urease activity of H. pylori, which is thought to be caused by inhibition of UreA and UreB expressions by evodiamine. In summary, these data indicate that evodiamine may restrict colonization and survival of $H$. pylori in the gastric mucosa by reducing the expression of urease. 


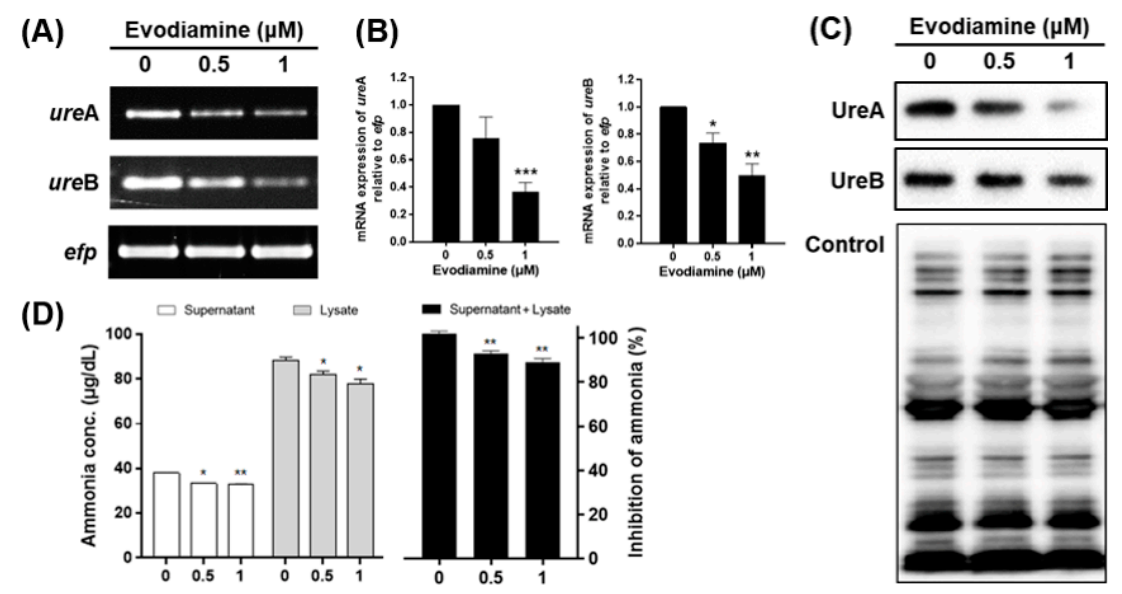

Figure 2. The inhibitory effects of evodiamine on the expression and activity of urease in H. pylori. (A) H. pylori was treated with indicated concentrations of evodiamine $(0.5$ and $1 \mu \mathrm{M})$ for $72 \mathrm{~h}$. RNA was subjected to RT-PCR to detect the mRNA expression levels of urease subunits (ureA and ureB). The expression of efp was used as an internal control. (B) Each band intensity was normalized using to efp. (C) The cell lysates were subjected to Western blot to detect UreA and UreB. The rabbit anti-H. pylori polyclonal antibody was used as an internal control. (D) After $72 \mathrm{~h}$, the supernatant and cell lysate were collected and then urease activity was determined by measuring ammonia levels. Each band intensity was normalized by protein quantification. Data were presented as mean $\pm \mathrm{SEM}$ of three independent experiments and analyzed by Student's $t$-test $\left({ }^{*} p<0.05,{ }^{* *} p<0.01\right.$ and $\left.{ }^{* * *} p<0.001\right)$.

\subsection{Reduced CagA and VacA Translocation to AGS Cells by Evodiamine}

When $H$. pylori adheres to the gastrointestinal mucosa, it secretes a number of virulence factors that can destroy gastric epithelial cells causing gastrointestinal disease. We examined whether evodiamine affects the amount of CagA and VacA proteins translocated into host cells. AGS cells were exposed to live bacteria at a multiplicity of infection (MOI) of 200 for $24 \mathrm{~h}$ in presence of evodiamine at two concentrations that do not affect cell viability (Figure 3A), then CagA and VacA proteins were detected in the lysates of $H$. pylori-infected AGS cells. However, both proteins were significantly decreased by evodiamine treatment (Figure 3B,C). Especially, VacA protein was dramatically decreased even by low dose of evodiamine treatment.

To find out why the amount of translocated proteins of CagA and VacA decreased, the mRNA and protein expression levels of CagA, VacA and each secretion system in H. pylori treated with evodiamine were assessed by RT-PCR and Western blot. Both the mRNA and protein levels of CagA and VacA in H. pylori were decreased by evodiamine treatment (Figure 3D-F). Furthermore, the mRNA expressions of virB2, virB4, virB5, virB6, virB7, vir B8, vir $\mathrm{B} 9$ and vir $\mathrm{D} 4$ were decreased by evodiamine treatment (Figure 3E,F). The mRNA and protein expressions of SecA in H. pylori were also suppressed by evodiamine treatment (Figure 3D-F).

Collectively, these data indicated that evodiamine not only reduced the expressions of CagA and VacA in H. pylori, but also reduced the translocation of CagA and VacA into host cells by downregulation of both the T4SS components required for CagA injection and SecA necessary for VacA secretion. 


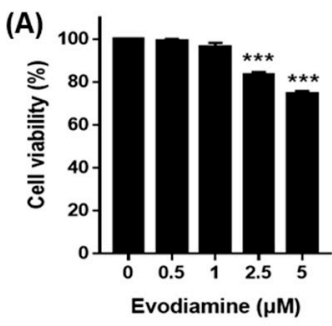

(B)

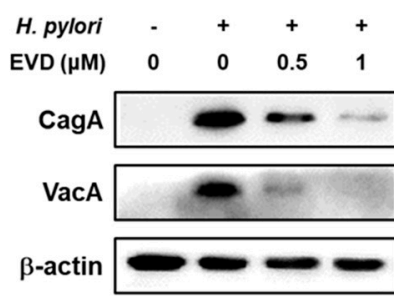

(D)

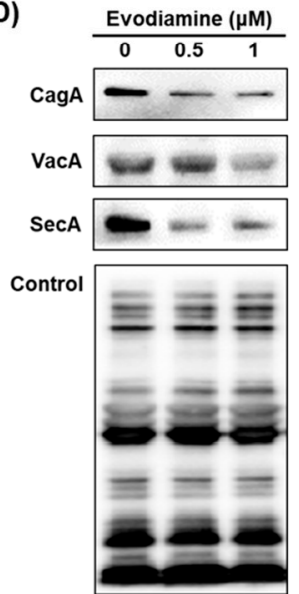

(E)
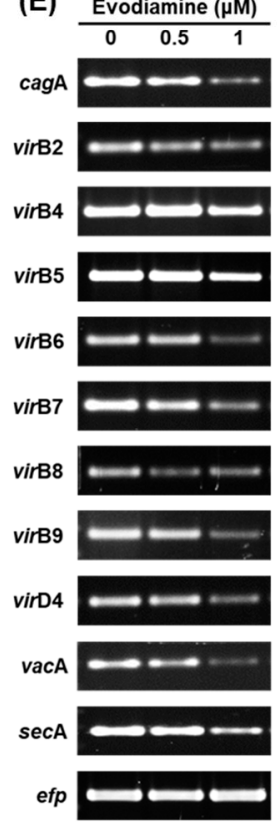

(F)
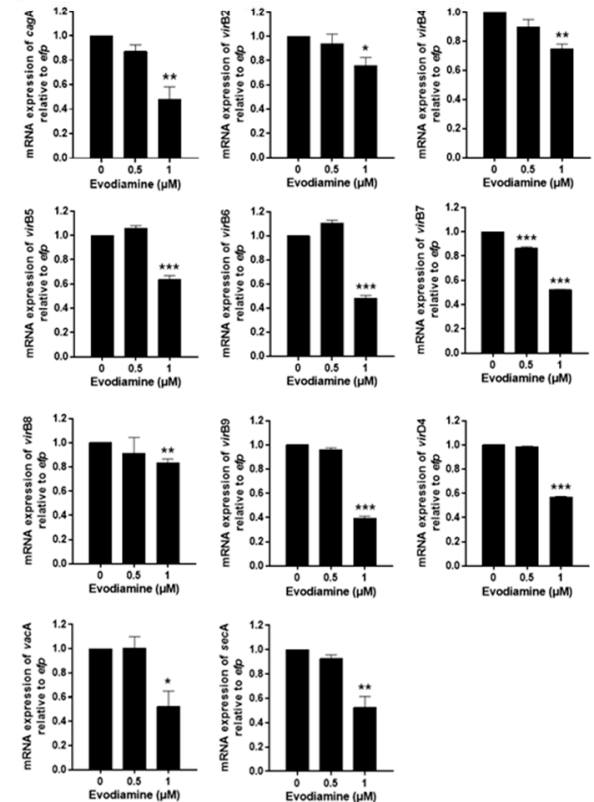

Figure 3. The inhibitory effects of evodiamine on CagA and VacA translocation to the gastric cell line. (A) AGS gastric cancer cells were treated with indicated dose of evodiamine $(0.5,1,2.5$ and $5 \mu \mathrm{M})$ for $24 \mathrm{~h}$ and cell viability was measured by the WST assay. AGS cells were infected with $H$. pylori (200 MOI) and treated with indicated concentrations of evodiamine $(0.5$ and $1 \mu \mathrm{M})$ for $24 \mathrm{~h}$. (B) After incubation, the cell lysates were collected and Western blot was then performed to detect CagA and VacA proteins. $\beta$-actin was used as an internal control. (C) Each band intensity was normalized to $\beta$-actin. H. pylori was treated with indicated concentrations of evodiamine $(0.5$ and $1 \mu \mathrm{M})$ for $72 \mathrm{~h}$. (D) The cell lysates were subjected to Western blot to detect CagA, VacA and SecA. The rabbit anti- $H$. pylori polyclonal antibody was used as an internal control. (E) RNA was subjected to RT-PCR to detect the mRNA expression level of cagA, T4SS components, vacA and secA. The expression of efp was used as an internal control. (F) Each band intensity was normalized to efp. Data were presented as mean \pm SEM of three independent experiments and analyzed by Student's $t$-test ( ${ }^{\# \#} p<0.001$, ${ }^{*} p<0.05,{ }^{* *} p<0.01$ and $\left.{ }^{* * *} p<0.001\right)$.

2.4. Decrease of Inflammatory Cytokines Induced by H. pylori Infection via Inhibition of MAPK and NF- $\kappa B$ Activation by Evodiamine

To investigate whether evodiamine inhibits H. pylori-induced activation of NF- $\mathrm{kB}$ through the MAPK signaling pathways and inflammatory responses, AGS cells infected with $H$. pylori were treated with evodiamine for $12 \mathrm{~h}$ (MAPK, IKB and NF-kB) and $24 \mathrm{~h}$ (IL-8). As shown in Figure 4A,B, total ERK1/2, p38 and JNK were not changed by H. pylori and/or evodiamine treatment in AGS cells. However, phospho-forms of ERK1/2, p38 and JNK increased more than 2-fold by H. pylori infection in AGS cells. Evodiamine, on the other hand, inhibited phosphorylation of ERK1/2, p38 and JNK induced by H. pylori from the concentration of $0.5 \mu \mathrm{M}$ of evodiamine. 

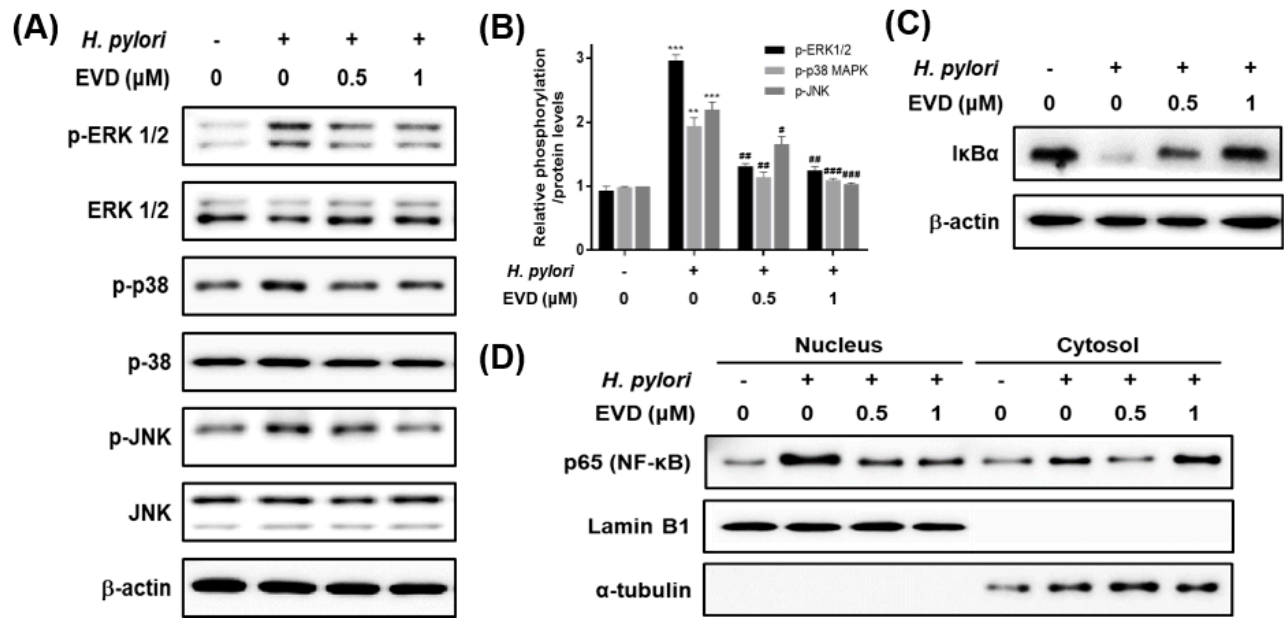

Figure 4. The inhibitory effects of evodiamine on H. pylori-induced activation of MAPK and NF-kB and degradation of $\mathrm{I} \mathrm{KB} \alpha$ in AGS cells infected with H. pylori. AGS cells were infected with H. pylori (200 MOI) and treated with indicated concentrations of evodiamine $(0.5$ and $1 \mu \mathrm{M})$ for $12 \mathrm{~h}$. (A) After incubation, cell lysates were collected and Western blot analysis of phosphorylated and total ERK $1 / 2$, JNK and p38 was performed. $\beta$-actin was used as an internal control. (B) Each band intensity was normalized to $\beta$-actin. Data were presented as mean \pm SEM. ${ }^{* *} p<0.01$ and ${ }^{* *} p<0.001$ vs. uninfected control. ${ }^{\#} p<0.05,{ }^{\# \#} p<0.01$ and ${ }^{\# \#} p<0.001$ vs. H. pylori-infected control without evodiamine treatment. (C) Western blot analysis of $\mathrm{I} \kappa \mathrm{B} \alpha$ was performed. $\beta$-actin was used as an internal control. (D) Cell lysates were separated into nuclear and cytosolic fractions, then performed to Western blot for NF- $\mathrm{kB}$. Lamin B1 was used as an internal control for nuclear fraction and $\alpha$-tubulin was used as an internal control for cytosolic fraction. EVD, evodiamine.

To determine whether NF- $\mathrm{kB}$ activated by $\mathrm{H}$. pylori is inhibited by treatment with evodiamine, I $\mathrm{K} \mathrm{B} \alpha$ degradation and NF- $\kappa \mathrm{B}$ activation were confirmed by Western blot. I $\mathrm{K} \mathrm{B} \alpha$ protein was decreased by $H$. pylori infection and recovered the I $\mathrm{K} \mathrm{B} \alpha$ protein level by evodiamine (Figure $4 \mathrm{C}$ ). It indirectly indicated that evodiamine reduced NF- $\mathrm{kB}$ activation by $H$. pylori infection. In addition, Western blot results for NF- $\mathrm{KB}$ in each fraction showed that NF- $\mathrm{KB}$ in the nucleus was increased by H. pylori infection, but it was reduced by evodiamine treatment (Figure 4D).

NF- $\mathrm{KB}$ has a dominant role in H. pylori-induced IL-8 secretion from gastric epithelial cells. The protein level of IL-8 was unaffected by evodiamine treatment alone. However, $H$. pylori-infection increased IL-8 level and evodiamine significantly decreased IL-8 production by $27 \%$ compared to the $H$. pylori-infected AGS cells without evodiamine (Figure 5 ). Collectively, these results suggested that evodiamine inhibited upregulated MAPK signaling pathway and NF- $\mathrm{kB}$ by H. pylori infection, which may lead to reduction of IL-8 inflammatory cytokine in the gastric epithelial cells.

\section{Discussion}

H. pylori infection is one of the critical risk factors for gastric cancer [34] and is responsible for $75 \%$ of all the gastric cancer cases [35,36]. However, numerous reports have suggested the prevalence of clarithromycin resistance and the limitation of current first-line therapy [37-39]. Therefore, development of a new therapeutic or supportive agent to help eradication of H. pylori is necessary. Evodiamine has anti-bacterial effect on Klebsiella pneumoniae, a Gram-negative bacterium [40]. In addition, evodiamine was suggested to have anti-inflammatory effect on macrophage and different types of epithelial cells through inhibition of NF- $\mathrm{KB}$ signaling [30,41,42]. In this study, thus, the inhibitory effect of evodiamine on $H$. pylori growth and $H$. pylori-induced inflammation was investigated.

The MIC of evodiamine against $H$. pylori reference strains was $20 \mu \mathrm{M}(6.07 \mu \mathrm{g} / \mathrm{mL})$ or $40 \mu \mathrm{M}(12.13 \mu \mathrm{g} / \mathrm{mL})$ in the agar dilution method (Figure 1B), whereas that was $5 \mu \mathrm{M}$ $(1.52 \mu \mathrm{g} / \mathrm{mL})$ in the broth dilution method (Figure 1C). Drugs can diffuse only on the surface of agar plate; however, in broth medium, they can act continuously and directly on bacteria as they grow. It is estimated that the reason why the MIC in the broth test showed 
lower than that of agar test. Evodiae rutaecarpa extract has been known that it contains quinolone alkaloids such as evocarpine and dihydroevocarpine and indoloquinazoline alkaloids such as evodiamine and rutaecarpine. Norio Hamasaki et al. reported that the mixture fractionated from Evodiae rutaecarpa containing evocarpine and 1-methyl-2-[(Z)7-trideceny1]10-4-(1H)-quinolone (10:1), the quinolone alkaloids compounds, inhibited the growth of $H$. pylori at the lowest concentration, $2 \mu \mathrm{g} / \mathrm{mL}$, among the fractions by the disk method [43]. Along with other substances constituting the crude extract of Evodiae rutaecarpa, evodiamine also seems to affect the anti-H. pylori activity of the extract.

From H. pylori isolated from patients, it was confirmed that bacterial growth was inhibited at even lower concentrations than that of reference strains as well as about half of them showed the same MIC as the reference strains (Table 1). The antibiotic susceptibility results according to the Clinical \& Laboratory Standard Institute (CLSI) guidelines for 50 clinical strains were shown in Supplementary Data 1. Among the isolates, 7 of 8 clarithromycin-resistant strains and 10 of 11 strains which are resistant to more than one antibiotic were inhibited by evodiamine at a concentration of less than $40 \mu \mathrm{M}$ (data not shown). The MIC in the broth dilution method was lower than the result from the agar method (Figure 1B,C). It suggests that low concentrations of evodiamine may have antibacterial effect on $H$. pylori in clinical use of evodiamine. Furthermore, H. pylori which could not be eliminated due to antibiotic resistance, is also thought to be effectively eradicated by evodiamine.

Evodiamine inhibited H. pylori growth via downregulation of replication and transcription machinery of H. pylori essential for survival (Figure 1D-F). DnaN and RpoB, especially, have been used for target of antibiotics. Streptomyces-derived griselimycin is highly active against Mycobacterium tuberculosis by inhibiting the DNA polymerase sliding clamp DnaN [44]. In addition, rifampin targets RpoB to inhibit transcription of $M$. tuberculosis [45]. It has been reported that increased expression of RpoB is associated with survival and growth in rifampin [46]. Collectively, as it is indispensable for replication or transcription of bacteria, this result suggests that evodiamine may be one of the mechanisms that inhibit the growth of $H$. pylori. Furthermore, reduction of transcription means that proteins produced by $H$. pylori including virulence factors may also be reduced, which is consistent with this study.

Downregulation of urease subunits by evodiamine may contribute to inhibit initial colonization of $H$. pylori to the gastric epithelium and survive under acidic conditions (Figure 2). It has been reported that the methanol extract of Evodiae rutaecarpa inhibits the urease activity of $H$. pylori [25]; however, it has been not known which substance affects yet. Rho TC et al. demonstrated that quinolone alkaloids had no inhibitory effect on urease activity of H. pylori [47]. Based on Figure 2D, it is assumed that evodiamine affects the inhibition of urease activity. Especially, decrease of UreB expression by evodiamine results in the reduced enzymatic activity of urease in H. pylori. Moreover, urease activity may be responsible for damage to the gastric epithelium through interaction with the immune system. Fan $\mathrm{X}$ et al. reported that urease binds to major histocompatibility complex (MHC) class II and induces apoptosis of gastric epithelial cells [48]. Ellen J et al. also reported that the UreB interacts CD74 and that induces NF- $\mathrm{kB}$ activation and IL-8 production [49]. It implies that urease reduced by evodiamine potentially leads to the weakened immune responses during infection.

Evodiamine suppressed translocation of CagA and VacA into host cells, which may result from downregulation of the expressions of CagA and VacA as well as the secretion systems which are involved in translocation of them (Figure 3). The T4SS in H. pylori contributes to gastric cancer development by mediating entry of CagA [50]. In this study, the mRNA expressions of virB2, virB4-9 and virD4 were decreased by evodiamine treatment (Figure 3E,F). Among components of inner membrane complex (VirB4, VirB6, VirB8 and VirD4), VirB4 and VirD4 are especially required to regulate substrate recruitment and transport it into T4SS [51]. VirB7 and VirB9 are necessary for injection of CagA because they form a trans-membrane pore complex channel to pass the substrate through the periplasmic 
space and are anchored in the outer membrane [51,52]. T4SS external pilus composed of VirB2 and VirB5 proteins is also essential for making the connection between the recipient and donor cells [51-53]. Translocation of VacA across the inner membrane is mediated by Sec-dependent T5 $5_{a} S S$ [21]. Among Sec-dependent proteins, SecA is an ATPase which is bound to the complex of inner membrane bound Sec-related family proteins [54]. In the current study, the mRNA and protein levels of SecA were downregulated by evodiamine (Figure 3D-F). Taken together, since evodiamine not only reduced the production of $H$. pylori-secreting CagA and VacA proteins, but also reduced the components of T4SS and $\mathrm{T} 5{ }_{\mathrm{a}} \mathrm{SS}$, it is thought that the amount of CagA and VacA proteins that have translocated into the host cell may be reduced by evodiamine.

Chronic H. pylori infection leads to inflammation of the gastric mucosa. The chemokine, IL-8, whose secretion is induced by H. pylori plays a central role in the pathogenesis of gastritis. In the present study, evodiamine inhibited the activation of MAPK and the nuclear translocation of NF-KB in H. pylori-infected AGS cells (Figure 4). In addition, the protein level of IL-8 was significantly suppressed by evodiamine treatment (Figure 5), in parallel with the degradation of IKB $\alpha$ and inhibition of NF- $\mathrm{kB}$ activation as shown as Figure 4. CagA of $H$. pylori contributes to the secretion of IL-8 through MAPK and NF- $k B$ activation [18]. IL-8, a potent leukocyte chemoattractant and activating agent [55], induces the release of reactive oxygen species (ROS) [7,56]. ROS production in gastric epithelial cells is enhanced by CagA proteins of H. pylori [57] and the oxidative stress stimulates MAPK such as ERK, JNK and p38 and up-regulates transcription of NF- $\mathrm{BB}[56,58]$.

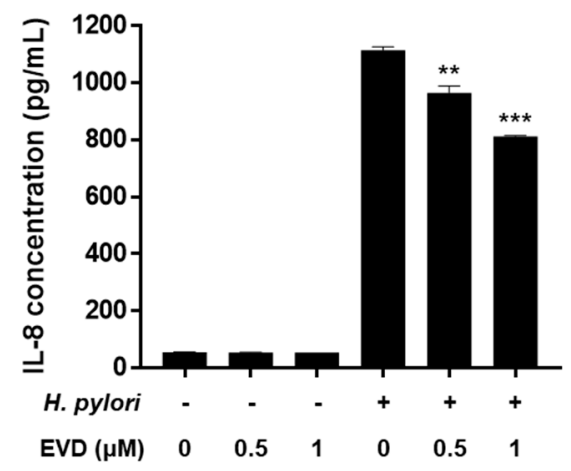

Figure 5. Inhibitory effect of evodiamine on IL-8 secretion induced by H. pylori in AGS cells. AGS cells were uninfected or infected with $H$. pylori (200 MOI) with indicated concentrations of evodiamine $(0.5$ and $1 \mu \mathrm{M})$. Culture medium were collected after $24 \mathrm{~h}$ and ELISA was performed to determine the IL-8 concentration. Data were presented as mean \pm SEM of three independent experiments and analyzed by Student's $t$-test ${ }^{* *} p<0.01$ and $\left.{ }^{* * *} p<0.001\right)$. EVD, evodiamine.

Furthermore, it has been also reported that VacA stimulation induces NF- $\mathrm{kB}$ activation in human eosinophils which can secrete IL-8 in an NF-KB-dependent manner [59]. However, Junzo Hisatsune et al. reported that VacA-induced IL-8 release was not observed in AGS cell lines [60]. Collectively, reduction of CagA translocation into host cells by evodiamine as shown in Figure 3B,C, in turn, leads to downregulation of MAPK activation, inhibition of NF- $\mathrm{kB}$ activation and eventually inhibition of IL-8 secretion induced by H. pylori infection. In addition, it is expected that evodiamine provides even more potent anti-inflammatory effect on $\mathrm{H}$. pylori-induced inflammation according to the result of dramatically decreased translocated VacA protein into AGS cells by evodiamine (Figure 3B,C).

Further studies are required to fully demonstrate anti-inflammatory mechanism of evodiamine against $H$. pylori. The MAPK pathway has been shown to mediate the activator protein-1 (AP-1) activation during H. pylori infection in gastric epithelial cells [61]. Therefore, it would be explained the complete anti-inflammatory mechanism of evodiamine by confirming the expression changes of AP-1. It would be also interesting to determine anti-inflammatory effect of evodiamine during $H$. pylori infection in lymphocyte cell lines 
and primary immune cells. In addition, in vivo studies seem to be necessary to evaluate the success of $H$. pylori eradication, anti-inflammatory effect and toxicity of evodiamine.

\section{Materials and Methods}

\subsection{Bacterial and Mammalian Cell Culture}

The H. pylori reference strains of ATCC 49503, ATCC 43504, ATCC 51932 and ATCC 700392 were purchased from the American Type Culture Collection (ATCC, Manassas, VA, USA) and the H. pylori SS1 strain was obtained from the Korean Type Culture Collection at Gyeongsang National University (Jinju, Korea). Fifty strains of H. pylori clinical isolates were isolated from 50 patients undergoing gastroscopic examination to confirm $H$. pylori infection at Yong-In Severance Hospital in Korea. The experiments were conducted with Institutional Review Board approval at Yonsei University Mirae Campus (IRB No. 1041849201705-BR-056-01). H. pylori were grown on Brucella agar plates (BD Biosciences, Franklin Lakes, NJ, USA) supplemented with 10\% bovine serum (BRL Life Technologies, Grand Island, NY, USA) under microaerophilic and 100 percent humidity conditions at $37^{\circ} \mathrm{C}$ and inspected after three to five days.

AGS gastric adenocarcinoma cells (ATCC CRL-1739) were purchased from the Korean Cell Line Bank (Seoul, Korea) and cultured in Dulbecco's modified Eagle's medium (DMEM, BRL Life Technologies) supplemented with 10\% fetal bovine serum (FBS, BRL Life Technologies) and streptomycin-penicillin $(100 \mu \mathrm{g} / \mathrm{mL}$ and $100 \mathrm{IU} / \mathrm{mL})$ (BRL Life Technologies). Cells were incubated at $37{ }^{\circ} \mathrm{C}$ in a humidified atmosphere with $5 \% \mathrm{CO}_{2}$. The experiments were conducted under Institutional Biosafety Committee approval at Yonsei University Mirae Campus (IBC No. 201909-P-006-01).

\subsection{Determination of $M I C$}

For agar dilution test, $10 \mu \mathrm{L}$ of the bacterial suspension (McFarland 2.0) were placed on the Mueller-Hinton agar (BD Biosciences) supplemented with 10\% bovine serum including indicated concentrations of evodiamine (Sigma-Aldrich, St Louis, MO, USA). The bacteria were incubated for $72 \mathrm{~h}$ and the minimum inhibitory concentration (MIC) was determined based on the lowest concentration of growth inhibition. For broth dilution test, various concentrations of evodiamine $(0.5 \sim 40 \mu \mathrm{M})$ were treated and the bacteria (McFarland 0.5) were incubated for $72 \mathrm{~h}$. All of the solutions were prepared in such a manner that the final dimethylsulfoxide (DMSO) concentration was the same in all treatments. Final optical density $(600 \mathrm{~nm})$ of the bacterial suspension was measured by spectrophotometry.

\subsection{RNA Extraction and Reverse Transcriptase-Polymerase Chain Reaction (RT-PCR)}

Cultured $H$. pylori were washed twice with sterile saline and total RNA was extracted using Trizol reagent (Invitrogen, Carlsbad, CA, USA) as described in the manufacturer's instructions. The PCR primer sequences used in this study are listed in Table 2 [62-67]. Efp (elongation factor P) was used as an internal control. The band intensity of PCR product was analyzed with the ImageLab software (Bio-Rad, Hercules, CA, USA). 
Table 2. List of primer sequences and PCR conditions for RT-PCR.

\begin{tabular}{|c|c|c|c|c|c|c|}
\hline \multirow{2}{*}{ Primers } & \multicolumn{2}{|c|}{ Sequences $\left(5^{\prime}-3^{\prime}\right)$} & \multirow{2}{*}{$\begin{array}{l}\text { Product } \\
\text { Length } \\
\text { (bp) }\end{array}$} & \multirow{2}{*}{$\begin{array}{c}\text { Annealing } \\
\text { Temperature } \\
\left({ }^{\circ} \mathrm{C}\right)\end{array}$} & \multirow{2}{*}{ Cycles } & \multirow{2}{*}{ Reference } \\
\hline & Forward & Reverse & & & & \\
\hline DnaA & GGGCATGACTTAGCGGTTA & TTAACGAATTGCACGCCAAC & 128 & 55 & 27 & \multirow{6}{*}{ [62] } \\
\hline DnaB & AATGGGCCGTTTATCGTCTC & CAAATCCGCTTGCAACTACG & 231 & 55 & 27 & \\
\hline DnaE & AATCCACCGGCTCCAAATAC & GCCAAACAAGTGTGGGAGTA & 184 & 55 & 27 & \\
\hline DnaN & GTTAGCGGTGGTTGAAAACG & CGGTTTCGCTATGCTCAGAA & 233 & 55 & 27 & \\
\hline DnaQ & CGCATGAAGCTTTGCAAGAA & GCATAGGCTCTATGGCTGAC & 244 & 55 & 27 & \\
\hline GyrA & GTGCATAGGCGTATTTT & CATTCTGGCTTCAGTGTAACG & 246 & 52 & 25 & \\
\hline RpoA & AGCGACACGTCTTCAGTAAC & ACAGCACCTTTGATCCСАTC & 224 & 55 & 22 & \multirow{4}{*}{ [65] } \\
\hline RpoB & TTTAGGTAAGCGCGTGGATT & AATCAGCTTTGGATGGAACG & 301 & 59 & 24 & \\
\hline RpoD & TCATCATCATTGCCGACTGG & GTCATGCGCAAACACATTCA & 152 & 55 & 26 & \\
\hline RpoN & GCCCTTGAAATCGTGCTTAC & ATGATGAGAGCTACCCGACA & 250 & 55 & 27 & \\
\hline UreA & GCCAATGGTAAATTAGTT & СТССTTAATTGTTTTTAC & 411 & 40 & 20 & \multirow{2}{*}{ [66] } \\
\hline UreB & TCТАТСССТАССССАСАAСС & CCATCCACGAACACATGGTA & 252 & 50 & 21 & \\
\hline CagA & GTCATAATGGCATAGAACCTGAA & ATTCCCTAGGGCGTCTAAATAA & 407 & 59 & 21 & \multirow{10}{*}{ [63] } \\
\hline VirB2 & CAGTCGCCTGACCTCTTTTGA & CGGTCACCAGTCCTGCAAC & 156 & 62 & 25 & \\
\hline VirB4 & GTTATAGGGGCAACCGGAAG & TTGAACGCGTCATTCAAAGC & 449 & 62 & 37 & \\
\hline VirB5 & TACAAGCGTCTGTGAAGCAG & GACCAACCAACAAGTGCTCA & 436 & 62 & 30 & \\
\hline VirB6 & CCTCAACACCGCCTTTGGTA & TAGCCGCTAGCAATCTGGTG & 225 & 62 & 25 & \\
\hline VirB7 & GATTACGCTCATAGGCGATGC & TGGCTGACTTCCTTGCAACA & 202 & 62 & 25 & \\
\hline VirB8 & GTTGATCCTTGCGATCCCTCA & CGCCGCTGTAACGAGTATTG & 218 & 62 & 25 & \\
\hline VirB9 & GCATGTCCTCTAGTCGTTCCA & TATCGTAGATGCGCCTGACC & 269 & 62 & 25 & \\
\hline VirD4 & CCGCAAGTTTCCATAGTGTC & GCGAGTTGGGAAACTGAAGA & 263 & 62 & 25 & \\
\hline SecA & AAAAATTTGACGCTGTGATCC & CCСССAAGCTCCTTAATTTC & 274 & 47 & 27 & \\
\hline VacA & AAACGACAAGAAAGAGATCAGT & CCAGCAAAAGGCCCATCAA & 291 & 57 & 22 & [64] \\
\hline Efp & GGCAATTTGGATGAGCGAGCTC & CTTCACCTTTTCAAGATACTC & 559 & 59 & 23 & [67] \\
\hline
\end{tabular}

\subsection{Protein Extraction and Western Blot}

AGS cells were seeded into $90 \mathrm{~mm}$ dishes at a density of $2.4 \times 10^{6}$ cells $/ 10 \mathrm{~mL}$ in DMEM containing $10 \%$ FBS without antibiotics and for $24 \mathrm{~h}$ prior to infection. H. pylori was added to the cells at a multiplicity of infection (MOI) of 200 in the absence or presence of evodiamine. After $12 \mathrm{~h}$, the infected cells were incubated gentamicin-containing $(25 \mu \mathrm{g} / \mathrm{mL})$ medium before the samples were harvested. The cell or bacteria was lysed with radio immunoprecipitation assay (RIPA) lysis buffer (Millipore, Billerica, MA, USA) containing a protease inhibitor cocktail. The cell lysates were incubated on ice for $10 \mathrm{~min}$, centrifuged at $12,000 \times g$ at $4{ }^{\circ} \mathrm{C}$ for $10 \mathrm{~min}$ and then the supernatants were collected.

Antibodies to detect CagA, VacA, Lamin B1, $\alpha$-tubulin and $\beta$-actin were purchased from Santa Cruz Biotechnology (Dallas, TX, USA) and the polyclonal antibody against whole H. pylori (ATCC 49503) was produced as previously described [68]. The antibodies to detect PARP, ERK, p-ERK, p38, p-p38, JNK, p-JNK, IкB $\alpha$ and NF- $\kappa B$ were purchased from Cell Signaling Technology (Danvers, MA, USA). The polyclonal antibody against whole H. pylori (ATCC 49503) or $\beta$-actin was used as an internal control for H. pylori or mammalian cell proteins, respectively.

\subsection{Urease Activity Test}

H. pylori ATCC 49503 strain was treated with the indicated concentrations of evodiamine $(0.5$ and $1 \mu \mathrm{M})$. After $72 \mathrm{~h}, 100 \mu \mathrm{L}$ of medium were collected, centrifuged at $5000 \times g$ for $10 \mathrm{~min}$ and then separated into medium and cells. The cells were lysed with $100 \mu \mathrm{L}$ of RIPA buffer containing a protease inhibitor at $4{ }^{\circ} \mathrm{C}$ for $10 \mathrm{~min}$. The lysates were centrifuged at $12,000 \times g$ at $4{ }^{\circ} \mathrm{C}$ for $10 \mathrm{~min}$ and the supernatants were collected. The collected lysates were quantified by Lowry protein assay. The medium was quantified by measuring the optical density at $600 \mathrm{~nm}$ using NanoQuant Infinite M200. After adding $5 \mu \mathrm{L}$ of $20 \%$ urea to the specimens respectively, the specimens were incubated at $37^{\circ} \mathrm{C}$ for $10 \mathrm{~min}$. Urease activity was determined by using an Asan Set Ammonia kit (Asan Pharmaceutical, Seoul, 
Korea) to measure ammonia levels according to manufacturer's instruction. The ammonia concentration of the specimens was calculated using the standard curve.

\subsection{Subcellular Fractionation}

Cellular cytosolic and nuclear fractions were prepared by incubating cells in $400 \mu \mathrm{L}$ of ice-cold hypotonic solution buffer (20 mM Tris- $\mathrm{HCl}, 3 \mathrm{mM} \mathrm{MgCl}$ and $10 \mathrm{mM} \mathrm{NaCl}_{2}$ ) with a protease inhibitor cocktail. The lysates were incubated for $10 \mathrm{~min}$ on ice and homogenized 40 times with a Dounce homogenizer (Wheaton, Millville, NJ, USA). The cell lysates were centrifuged at $5000 \times \mathrm{g}$ for $10 \mathrm{~min}$ at $4{ }^{\circ} \mathrm{C}$ and supernatant (cytosolic fraction) was transferred to a new tube and mixed with $5 \times$ SDS sample loading buffer. Nuclear pellet was washed once with hypotonic solution buffer to clear the nuclear debris and lysed with $2 \times$ SDS sample loading buffer. Before Western blot, nuclear fraction samples were sonicated for $5 \mathrm{~s}$ with $20 \mathrm{~Hz}$ (Vibracell, Danbury, CT, USA).

\subsection{Enzyme-Linked Immunosorbent Assay (ELISA)}

AGS cells were seeded into 6-well cell culture plates at a density at $2 \times 10^{5}$ cells $/ 2 \mathrm{~mL}$ in DMEM containing 10\% FBS without antibiotics and for $24 \mathrm{~h}$ prior to infection. H. pylori was added to the cells at the MOI of 200 in the absence or presence of evodiamine. After $12 \mathrm{~h}$, the infected cells were incubated gentamicin-containing $(25 \mu \mathrm{g} / \mathrm{mL})$ medium before the supernatants were harvested. The supernatant was collected and centrifuged at $5000 \times$ $g$ at $4{ }^{\circ} \mathrm{C}$ for $10 \mathrm{~min}$ to remove the host cells and cell debris. To determine the production of IL-8, $100 \mu \mathrm{L}$ of cell culture supernatants were analyzed by IL-8 human uncoated ELISA kit (Invitrogen) according to manufacturer's instruction.

\subsection{Statistical Analysis}

Data in the bar graphs are presented as mean \pm standard error of mean (SEM). All the statistical analyses were performed using GraphPad Prism 7.0 software (GraphPad Software, San Diego, CA, USA). All the data were analyzed by unpaired Student's $t$-test and $p<0.05$ was considered to be statistically significant.

Supplementary Materials: Supplementary materials can be found at https://www.mdpi.com/1422 $-0067 / 22 / 7 / 3385 / s 1$.

Author Contributions: J.Y.Y. have written the manuscript. J.Y.Y. and P.L. have performed the analysis results. J.-B.K. helped shape the research. S.-H.K. supervised the findings of this work and helped analysis and manuscript. All authors have read and agreed to the published version of the manuscript.

Funding: This work was supported by Korea Institute of Planning and Evaluation for Technology in Food, Agriculture and Forestry (IPET) through Future Innovation Food Technology Development Program, funded by Ministry of Agriculture, Food and Rural Affairs (MAFRA) (119023-3).

Institutional Review Board Statement: The study was conducted according to the guidelines of the Declaration of Helsinki and approved by the Institutional Review Board of Yonsei University Mirae Campus (IRB No. 1041849-201705-BR-056-01).

Informed Consent Statement: Not applicable.

Data Availability Statement: The data that support the findings of this study are available from the corresponding author upon reasonable request.

Conflicts of Interest: The authors have declared no conflict of interest.

\section{References}

1. Zali, H.; Rezaei-Tavirani, M.; Azodi, M. Gastric cancer: Prevention, risk factors and treatment. Gastroenterol. Hepatol. Bed Bench 2011, 4, 175-185.

2. Sitarz, R.; Skierucha, M.; Mielko, J.; Offerhaus, G.J.A.; Maciejewski, R.; Polkowski, W.P. Gastric cancer: Epidemiology, prevention, classification, and treatment. Cancer Manag. Res. 2018, 10, 239-248. [CrossRef]

3. Oakley, A.J. A structural view of bacterial DNA replication. Protein Sci. 2019, 28, 990-1004. [CrossRef] 
4. Terradot, L.; Zawilak-Pawlik, A. Structural insight into Helicobacter pylori DNA replication initiation. Gut Microbes 2010, 1, 330-334. [CrossRef] [PubMed]

5. Nitharwal, R.G.; Verma, V.; Dasgupta, S.; Dhar, S.K. Helicobacter pylori chromosomal DNA replication: Current status and future perspectives. FEBS Lett. 2010, 585, 7-17. [CrossRef]

6. Borin, B.N.; Tang, W.; Krezel, A.M. Helicobacter pylori RNA polymerase $\alpha$-subunit C-terminal domain shows features unique to $\varepsilon$-proteobacteria and binds NikR/DNA complexes. Protein Sci. 2014, 23, 454-463. [CrossRef] [PubMed]

7. Kusters, J.G.; van Vliet, A.H.M.; Kuipers, E.J. Pathogenesis of Helicobacter pylori Infection. Clin. Microbiol. Rev. 2006, 19, 449-490. [CrossRef] [PubMed]

8. Mobley, H.L. The role of Helicobacter pylori urease in the pathogenesis of gastritis and peptic ulceration. Aliment. Pharmacol. Ther 1996, 10 (Suppl. 1), 57-64. [CrossRef] [PubMed]

9. Blum, F.C.; Hu, H.Q.; Servetas, S.L.; Benoit, S.L.; Maier, R.J.; Maroney, M.J.; Merrell, D.S. Structure-function analyses of metalbinding sites of HypA reveal residues important for hydrogenase maturation in Helicobacter pylori. PLoS ONE 2017, 12, e0183260. [CrossRef] [PubMed]

10. Voland, P.; Weeks, D.L.; Marcus, E.A.; Prinz, C.; Sachs, G.; Scott, D. Interactions among the seven Helicobacter pylori proteins encoded by the urease gene cluster. Am. J. Physiol. Gastrointest. Liver Physiol. 2003, 284, G96-G106. [CrossRef]

11. Ansari, S.; Yamaoka, Y. Survival of Helicobacter pylori in gastric acidic territory. Helicobacter 2017, 22. [CrossRef]

12. Futagami, S.; Hiratsuka, T.; Tatsuguchi, A.; Suzuki, K.; Kusunoki, M.; Shinji, Y.; Shinoki, K.; Iizumi, T.; Akamatsu, T.; Nishigaki, $\mathrm{H}$; ; et al. Monocyte chemoattractant protein 1 (MCP-1) released from Helicobacter pylori stimulated gastric epithelial cells induces cyclooxygenase 2 expression and activation in T cells. Gut 2003, 52, 1257-1264. [CrossRef] [PubMed]

13. Sebkova, L.; Pellicanò, A.; Monteleone, G.; Grazioli, B.; Guarnieri, G.; Imeneo, M.; Pallone, F.; Luzza, F. Extracellular signalregulated protein kinase mediates interleukin 17 (IL-17)-induced IL-8 secretion in Helicobacter pylori-infected human gastric epithelial cells. Infect. Immun. 2004, 72, 5019-5026. [CrossRef]

14. Kim, D.J.; Park, K.-S.; Kim, J.-H.; Yang, S.-H.; Yoon, J.Y.; Han, B.-G.; Kim, H.S.; Lee, S.J.; Jang, J.Y.; Kim, K.H.; et al. Helicobacter pylori proinflammatory protein up-regulates NF-кB as a cell-translocating Ser/Thr kinase. Proc. Natl. Acad. Sci. USA 2010, 107, 21418-21423. [CrossRef]

15. Tegtmeyer, N.; Wessler, S.; Backert, S. Role of the cag-pathogenicity island encoded type IV secretion system in Helicobacter pylori pathogenesis. FEBS J. 2011, 278, 1190-1202. [CrossRef]

16. Hu, B.; Khara, P.; Song, L.; Lin, A.S.; Frick-Cheng, A.E.; Harvey, M.L.; Cover, T.L.; Christie, P.J. In situ molecular architecture of the Helicobacter pylori cag type IV secretion system. mBio 2019, 10, e00849-19. [CrossRef]

17. Chung, J.M.; Sheedlo, M.J.; Campbell, A.M.; Sawhney, N.; Frick-Cheng, A.E.; Lacy, D.B.; Cover, T.L.; Ohi, M.D. Structure of the Helicobacter pylori Cag type IV secretion system. eLife 2019, 8. [CrossRef]

18. Higuchi, M.; Tsutsumi, R.; Higashi, H.; Hatakeyama, M. Conditional gene silencing utilizing the lac repressor reveals a role of SHP-2 in cagA-positive Helicobacter pylori pathogenicity. Cancer Sci. 2004, 95, 442-447. [CrossRef] [PubMed]

19. Hatakeyama, M. Structure and function of Helicobacter pylori CagA, the first-identified bacterial protein involved in human cancer. Proc. Jpn. Acad. Ser. B Phys. Biol. Sci. 2017, 93, 196-219. [CrossRef] [PubMed]

20. Seo, J.H.; Lim, J.W.; Kim, H. Helicobacter pylori in a Korean isolate activates mitogen-activated protein kinases, AP-1, and NF- $\mathrm{kB}$ and induces chemokine expression in gastric epithelial AGS cells. Lab. Investig. 2003, 84, 49-62. [CrossRef]

21. Boquet, P.; Ricci, V. Intoxication strategy of Helicobacter pylori VacA toxin. Trends Microbiol. 2012, 20, 165-174. [CrossRef]

22. Leyton, D.L.; Rossiter, A.E.; Henderson, I.R. From self sufficiency to dependence: Mechanisms and factors important for autotransporter biogenesis. Nat. Rev. Microbiol. 2012, 10, 213-225. [CrossRef] [PubMed]

23. Kim, S.-H.; Woo, H.; Park, M.; Rhee, K.-J.; Moon, C.; Lee, D.; Seo, W.D.; Kim, J.B. Cyanidin 3-O-glucoside reduces Helicobacter pylori VacA-induced cell death of gastric KATO III cells through inhibition of the SecA pathway. Int. J. Med. Sci. 2014, 11, 742-747. [CrossRef]

24. Lee, M.H.; Yang, J.Y.; Cho, Y.; Woo, H.J.; Kwon, H.J.; Kim, D.H.; Park, M.; Moon, C.; Yeon, M.J.; Kim, H.W.; et al. Inhibitory effects of menadione on Helicobacter pylori growth and Helicobacter pylori-induced inflammation via NF-кB inhibition. Int. J. Mol. Sci. 2019, 20, 1169. [CrossRef] [PubMed]

25. Yang, J.Y.; Lee, P.; Kim, J.B. Effect of Evodiae fructus methanol extract on virulence-related genes' expression of Helicobacter pylori. Korean J. Clin. Lab. Sci. 2019, 51, 316-322. [CrossRef]

26. Nguyen, N.V.T.; Lee, K.R.; Lee, Y.J.; Choi, S.; Kang, J.S.; Mar, W.; Kim, K.H. Chiral high-performance liquid chromatographic separation of evodiamine enantiomers and rutaecarpine, isolated from Evodiae fructus. J. Pharm. Biomed. Anal. 2013, 81-82, 151-159. [CrossRef]

27. Chiou, W.-F.; Chou, C.-J.; Shum, A.Y.-C.; Chen, C.-F. The vasorelaxant effect of evodiamine in rat isolated mesenteric arteries: Mode of action. Eur. J. Pharmacol. 1992, 215, 277-283. [CrossRef]

28. Kobayashi, Y.; Nakano, Y.; Kizaki, M.; Hoshikuma, K.; Yokoo, Y.; Kamiya, T. Capsaicin-like anti-obese activities of evodiamine from fruits of Evodia rutaecarpa, a vanilloid receptor agonist. Planta Med. 2001, 67, 628-633. [CrossRef]

29. Shin, Y.-W.; Bae, E.-A.; Cai, X.F.; Lee, J.J.; Kim, D.-H. In vitro and in vivo antiallergic effect of the fructus of Evodia rutaecarpa and its constituents. Biol. Pharm. Bull. 2007, 30, 197-199. [CrossRef]

30. Chiou, W.-F.; Sung, Y.-J.; Liao, J.-F.; Shum, A.Y.-C.; Chen, C.-F. Inhibitory effect of dehydroevodiamine and evodiamine on nitric oxide production in cultured murine macrophages. J. Nat. Prod. 1997, 60, 708-711. [CrossRef] 
31. Ogasawara, M.; Matsubara, T.; Suzuki, H. Inhibitory effects of evodiamine on in vitro invasion and experimental lung metastasis of murine colon cancer cells. Biol. Pharm. Bull. 2001, 24, 917-920. [CrossRef] [PubMed]

32. Liao, C.-H.; Pan, S.-L.; Guh, J.-H.; Chang, Y.-L.; Pai, H.-C.; Lin, C.-H.; Teng, C.-M. Antitumor mechanism of evodiamine, a constituent from Chinese herb Evodiae fructus, in human multiple-drug resistant breast cancer NCI/ADR-RES cells in vitro and in vivo. Carcinogenesis 2005, 26, 968-975. [CrossRef] [PubMed]

33. Kan, S.-F.; Yu, C.-H.; Pu, H.-F.; Hsu, J.-M.; Chen, M.-J.; Wang, P.S. Anti-proliferative effects of evodiamine on human prostate cancer cell lines DU145 and PC3. J. Cell. Biochem. 2007, 101, 44-56. [CrossRef] [PubMed]

34. Kersulyte, D.; Mukhopadhyay, A.K.; Velapatiño, B.; Su, W.; Pan, Z.; Garcia, C.; Hernandez, V.; Valdez, Y.; Mistry, R.S.; Gilman, R.H.; et al. Differences in genotypes of Helicobacter pylori from different human populations. J. Bacteriol. 2000, 182, 3210-3218. [CrossRef] [PubMed]

35. Testino, G.; Cornaggia, M.; Valentin, M. Helicobacter pylori, pre-neoplastic changes, gastric cancer: A point of view. Eur. J. Gastroenterol. Hepatol. 1999, 11, 357-359. [CrossRef]

36. Peleteiro, B.; Bastos, A.; Ferro, A.; Lunet, N. Prevalence of Helicobacter pylori infection worldwide: A systematic review of studies with national coverage. Dig. Dis. Sci. 2014, 59, 1698-1709. [CrossRef]

37. Zhang, Y.-X.; Zhou, L.-Y.; Song, Z.-Q.; Zhang, J.-Z.; He, L.-H.; Ding, Y. Primary antibiotic resistance of Helicobacter pylori strains isolated from patients with dyspeptic symptoms in Beijing: A prospective serial study. World J. Gastroenterol. 2015, 21, $2786-2792$. [CrossRef]

38. Wu, I.-T.; Chuah, S.-K.; Lee, C.-H.; Liang, C.-M.; Lu, L.-S.; Kuo, Y.-H.; Yen, Y.-H.; Hu, M.-L.; Chou, Y.-P.; Yang, S.-C.; et al. Five-year sequential changes in secondary antibiotic resistance of Helicobacter pylori in Taiwan. World J. Gastroenterol. 2015, 21, 10669-10674. [CrossRef]

39. Ghotaslou, R.; Leylabadlo, H.E.; Asl, Y.M. Prevalence of antibiotic resistance in Helicobacter pylori: A recent literature review. World J. Methodol. 2015, 5, 164-174. [CrossRef]

40. Wu, J.-Y.; Chang, M.-C.; Chen, C.-S.; Lin, H.-C.; Tsai, H.-P.; Yang, C.-C.; Yang, C.-H.; Lin, C.-M. Topoisomerase I inhibitor evodiamine acts as an antibacterial agent against drug-resistant Klebsiella pneumoniae. Planta Med. 2013, 79, 27-29. [CrossRef]

41. Choi, Y.H.; Shin, E.M.; Kim, Y.S.; Cai, X.F.; Lee, J.J.; Kim, H.P. Anti-inflammatory principles from the fruits of Evodia rutaecarpa and their cellular action mechanisms. Arch. Pharmacal Res. 2006, 29, 293-297. [CrossRef] [PubMed]

42. Shi, Y.; Hua, Q.; Li, N.; Zhao, M.; Cui, Y. Protective effects of evodiamine against LPS-induced acute kidney injury through regulation of ROS-NF-kB-mediated inflammation. Evid. Based Complement. Altern. Med. 2019, 2019, 2190847. [CrossRef] [PubMed]

43. Hamasaki, N.; Ishii, E.; Tominaga, K.; Tezuka, Y.; Nagaoka, T.; Kadota, S.; Kuroki, T.; Yano, I. Highly selective antibacterial activity of novel alkyl quinolone alkaloids from a Chinese herbal medicine, Gosyuyu (Wu-Chu-Yu), against Helicobacter pylori in vitro. Microbiol. Immunol. 2000, 44, 9-15. [CrossRef] [PubMed]

44. Kling, A.; Lukat, P.; Almeida, D.V.; Bauer, A.; Fontaine, E.; Sordello, S.; Zaburannyi, N.; Herrmann, J.; Wenzel, S.C.; König, C.; et al. Antibiotics. Targeting DnaN for tuberculosis therapy using novel griselimycins. Science 2015, 348, 1106-1112. [CrossRef]

45. Campbell, E.A.; Korzheva, N.; Mustaev, A.; Murakami, K.; Nair, S.; Goldfarb, A.; Darst, S.A. Structural mechanism for rifampicin inhibition of bacterial RNA polymerase. Cell 2001, 104, 901-912. [CrossRef]

46. Zhu, J.-H.; Wang, B.-W.; Pan, M.; Zeng, Y.-N.; Rego, H.; Javid, B. Rifampicin can induce antibiotic tolerance in mycobacteria via paradoxical changes in rpoB transcription. Nat. Commun. 2018, 9, 1-13. [CrossRef]

47. Rho, T.C.; Bae, E.-A.; Kim, D.-H.; Oh, W.K.; Kim, B.Y.; Ahn, J.S.; Lee, H.S. Anti-Helicobacter pylori activity of quinolone alkaloids from Evodiae Fructus. Biol. Pharm. Bull. 1999, 22, 1141-1143. [CrossRef]

48. Fan, X.; Gunasena, H.; Cheng, Z.; Espejo, R.; Crowe, S.E.; Ernst, P.B.; Reyes, V.E. Helicobacter pylori Urease binds to class II MHC on gastric epithelial cells and induces their apoptosis. J. Immunol. 2000, 165, 1918-1924. [CrossRef]

49. Beswick, E.J.; Pinchuk, I.V.; Minch, K.; Suarez, G.; Sierra, J.C.; Yamaoka, Y.; Reyes, V.E. The Helicobacter pylori urease B subunit binds to CD74 on gastric epithelial cells and induces NF-kB activation and interleukin-8 production. Infect. Immun. 2006, 74, 1148-1155. [CrossRef]

50. Frick-Cheng, A.E.; Pyburn, T.M.; Voss, B.J.; McDonald, W.H.; Ohi, M.D.; Cover, T.L. Molecular and structural analysis of the Helicobacter pylori cag type IV secretion system core complex. mBio 2016, 7, e02001-15. [CrossRef] [PubMed]

51. Merino, E.; Flores-Encarnación, M.; Aguilar-Gutiérrez, G.R. Functional interaction and structural characteristics of unique components of Helicobacter pylori T4SS. FEBS J. 2017, 284, 3540-3549. [CrossRef]

52. Redzej, A.; Ukleja, M.; Connery, S.; Trokter, M.; Felisberto-Rodrigues, C.; Cryar, A.; Thalassinos, K.; Hayward, R.D.; Orlova, E.V.; Waksman, G. Structure of a VirD4 coupling protein bound to a VirB type IV secretion machinery. EMBO J. 2017, 36, 3080-3095. [CrossRef] [PubMed]

53. Terradot, L.; Waksman, G. Architecture of the Helicobacter pylori Cag-type IV secretion system. FEBS J. 2011, $278,1213-1222$. [CrossRef] [PubMed]

54. Mobley, H.L.T.; Mendz, G.L.; Hazell, S.L. Overview. In Helicobacter pylori: Physiology and Genetics; Mobley, H.L.T., Mendz, G.L., Hazell, S.L., Eds.; ASM Press: Washington, DC, USA, 2001.

55. Schmausser, B.; Josenhans, C.; Endrich, S.; Suerbaum, S.; Sitaru, C.; Andrulis, M.; Brändlein, S.; Rieckmann, P.; MüllerHermelink, H.K.; Eck, M. Downregulation of CXCR1 and CXCR2 expression on human neutrophils by Helicobacter pylori: A new pathomechanism in H. pylori infection? Infect. Immun. 2004, 72, 6773-6779. [CrossRef] 
56. Kim, J.-M.; Kim, K.-M.; Park, E.-H.; Seo, J.-H.; Song, J.-Y.; Shin, S.-C.; Kang, H.-L.; Lee, W.-K.; Cho, M.-J.; Rhee, K.-H.; et al. Anthocyanins from black soybean inhibit Helicobacter pylori-induced inflammation in human gastric epithelial AGS cells. Microbiol. Immunol. 2013, 57, 366-373. [CrossRef] [PubMed]

57. Suzuki, H.; Suzuki, M.; Mori, M.; Kitahora, T.; Yokoyama, H.; Miura, S.; Hibi, T.; Ishii, H. Augmented levels of gastric mucosal leucocyte activation by infection with cagA gene-positive Helicobacter pylori. J. Gastroenterol. Hepatol. 1998, 13, 294-300. [CrossRef] [PubMed]

58. Kim, H.; Lim, J.W.; Kim, K.H. Helicobacter pylori-induced expression of interleukin-8 and cyclooxygenase-2 in AGS gastric epithelial cells: Mediation by nuclear factor-кB. Scand. J. Gastroenterol. 2001, 36, 706-716. [CrossRef]

59. Kim, J.M.; Kim, J.S.; Lee, J.Y.; Kim, Y.-J.; Youn, H.-J.; Kim, I.Y.; Chee, Y.J.; Oh, Y.-K.; Kim, N.; Jung, H.C.; et al. Vacuolating cytotoxin in Helicobacter pylori water-soluble proteins upregulates chemokine expression in human eosinophils via Ca2+ influx, mitochondrial reactive oxygen intermediates, and NF-KB activation. Infect. Immun. 2007, 75, 3373-3381. [CrossRef]

60. Hisatsune, J.; Nakayama, M.; Isomoto, H.; Kurazono, H.; Mukaida, N.; Mukhopadhyay, A.K.; Azuma, T.; Yamaoka, Y.; Sap, J.; Yamasaki, E.; et al. Molecular characterization of Helicobacter pylori VacA induction of IL-8 in U937 cells reveals a prominent role for $\mathrm{p} 38 \mathrm{MAPK}$ in activating transcription factor-2, cAMP response element binding protein, and NF- $\mathrm{KB}$ activation. J. Immunol. 2008, 180, 5017-5027. [CrossRef]

61. Meyer-Ter-Vehn, T.; Covacci, A.; Kist, M.; Pahl, H.L. Helicobacter pylori activates mitogen-activated protein kinase cascades and induces expression of the proto-oncogenes c-fos and c-jun. J. Biol. Chem. 2000, 275, 16064-16072. [CrossRef]

62. Lee, M.H.; Kwon, H.J.; Kim, D.H.; Yang, J.Y.; Cho, Y.; Woo, H.T.; Yeon, M.J.; Park, M.; Moon, C.; Kim, S.H.; et al. Kinetin inhibits growth of Helicobacter pylori by down-regulation of replication genes. Int. J. Clin. Exp. Med. 2017, 10, 795-801.

63. Yeon, M.J.; Lee, M.H.; Kim, D.H.; Yang, J.Y.; Woo, H.J.; Kwon, H.J.; Moon, C.; Kim, S.-H.; Kim, J.-B. Anti-inflammatory effects of Kaempferol on Helicobacter pylori-induced inflammation. Biosci. Biotechnol. Biochem. 2019, 83, 166-173. [CrossRef] [PubMed]

64. Boonjakuakul, J.K.; Canfield, D.R.; Solnick, J.V. Comparison of Helicobacter pylori virulence gene expression in vitro and in the Rhesus Macaque. Infect. Immun. 2005, 73, 4895-4904. [CrossRef] [PubMed]

65. Tharmalingam, N.; Kim, S.-H.; Park, M.; Woo, H.J.; Kim, H.W.; Yang, J.Y.; Rhee, K.-J.; Kim, J.B. Inhibitory effect of piperine on Helicobacter pylori growth and adhesion to gastric adenocarcinoma cells. Infect. Agents Cancer 2014, 9, 43. [CrossRef]

66. Clayton, C.; Kleanthous, K.; Tabaqchali, S. Detection and identification of Helicobacter pylori by the polymerase chain reaction. J. Clin. Pathol. 1991, 44, 515-516. [CrossRef] [PubMed]

67. Jolley, K.A.; Maiden, M.C.J. BIGSdb: Scalable analysis of bacterial genome variation at the population level. BMC Bioinform. 2010, 11, 595. [CrossRef]

68. Sharma, S.A.A.; Tummuru, M.K.; Blaser, M.J.; Kerr, L.D. Activation of IL-8 gene expression by Helicobacter pylori is regulated by transcription factor nuclear factor-kappa B in gastric epithelial cells. J. Immunol. 1998, 160, 2401-2407. [PubMed] 